\title{
Demographic profile of patients and clinical characteristics of dental emergencies at the outpatient clinic of a Brazilian Dental School
}

\author{
Perfil demográfico dos pacientes e características clínicas \\ das urgências dentárias no Serviço de Plantão \\ de uma Faculdade Brasileira de Odontologia
}

\author{
Andrea Cardoso PEREIRA ${ }^{1}$ iD 0000-0001-7041-9649 \\ Ana Carolina Correia Laurindo de CERQUEIRA NETO1 ${ }^{1}$ iD 0000-0001-8383-6986 \\ Alexandre Augusto ZAIA ${ }^{1}$ iD 0000-0003-1354-1466 \\ Brenda Paula Figueiredo de Almeida GOMES ${ }^{1}$ iD 0000-0002-8449-0646 \\ José Flávio Affonso de ALMEIDA' ${ }^{1}$ iD 0000-0002-5874-9247 \\ Adriana de Jesus SOARES ${ }^{1}$ ID 0000-0002-8078-1606
}

\section{ABSTRACT}

Objective: This retrospective study evaluated the demographic profile of patients and the clinical characteristics of dental emergencies in a brazilian university outpatient clinic. Methods: During the period from June 2013 to May 2014, data were collected from 1.345 clinical records. Chief complaint, gender, age, systemic alteration, clinical inspection of the affected tooth, pulp and periapical diagnosis, the type of procedure performed and whether there was the need for post-operative systemic medication. Data were analyzed using the SAS software and chi-square test was used to verify the presence or absence of statistical significance at a level of $5 \%$. Results: Dental pain (53.3\%) was the main reason why people attended the emergency service, that is, female patients $(63.1 \%)$, aged $29-48$ years old $(42 \%)$, patients without systemic conditions (75\%), and patients with decayed teeth (25\%). In addition, involvement of lower molars (29.81\%) and diagnosis of irreversible pulpitis (30.42\%) were the most frequent findings. Emergency endodontic treatment (45.8\%) was the most performed procedure. Irreversible pulpitis (30.4\%) and pulp necrosis associated with acute apical periodontitis (21.9\%) were the most frequent conditions requiring emergency endodontic treatment, and in most cases, there was no need for post-operative systemic medications (95.7\%). Conclusion: The prevalence of endodontic emergencies during the period of one year emphasizes the need for more accurate diagnosis and the importance of providing this service to the population.

Indexing terms: Emergency relief. Endodontics. Pain.

\footnotetext{
1 Universidade Estadual de Campinas, Faculdade de Odontologia de Piracicaba, Departamento de Odontologia Restauradora. Av. Limeira, 901, Areião, 13414-903, Piracicaba, SP, Brasil. Correspondência para / Correspondence to: AJ SOARES. E-mail: <ajsoares.endo@uol.com.br>.

$\mathbf{v} \mathbf{v}$

Como citar estar artigo / How to cite this article

Pereira AC, Cerqueira Neto ACCL, Zaia AA, Gomes BPFA, Almeida JFA, Soares AJ. Demographic profile of patients and clinical characteristics of dental emergencies at the outpatient clinic of a Brazilian Dental School. RGO, Rev Gaúch Odontol. 2018;66(4):345-351. http://dx.doi. org/10.1590/1981-863720180004000083530
} 


\section{RESUMO}

Objetivo: Este estudo retrospectivo avaliou o perfil demográfico dos pacientes e as características clínicas das urgências dentárias em um Serviço de Plantão de Urgências de uma Faculdade brasileira de Odontologia. Métodos: Durante o período de junho de 2013 a maio de 2014, os dados foram coletados de 1.345 registros clínicos, com informações sobre a queixa principal, gênero, idade, alteração sistêmica, inspeção clínica do dente afetado, diagnóstico pulpar e periapical, o tipo de procedimento realizado e se houve necessidade de medicação sistêmica pós-operatória. Os dados foram analisados usando o software SAS e o teste do qui-quadrado foi utilizado para verificar a presença ou ausência de significância estatística ao nível de 5\%. Resultados: A dor dental (53,3\%) foi a queixa principal mais encontrada. Pacientes do gênero feminino (63,1\%), com idade entre 29-48 anos (42\%), sem condições sistêmicas (75\%) e com dentes cariados (25\%) foram os mais prevalentes. Além disso, o envolvimento de molares inferiores (29,81\%) e o diagnóstico de pulpite irreversivel (30,42\%) foram os achados mais frequentes. O tratamento endodôntico de urgência (45,8\%) foi o procedimento mais realizado. A pulpite irreversível (30,4\%) e a necrose pulpar associada a periodontite apical aguda (21,9\%) foram as condições mais frequentes que necessitaram de tratamento endodôntico de urgência e, na maioria dos casos, não houve prescrição de medicamentos sistêmicos pós-operatórios (95,7\%). Conclusão: A prevalência de urgências endodônticas durante o período de um ano enfatiza a necessidade de diagnósticos mais precisos e a importância de oferecer esse serviço à população.

Termos de indexação: Dor. Endodontia. Socorro de urgência.

\section{INTRODUCTION}

People use dental emergency services to resolve their complaints immediately, such as alveolar bone fractures, avulsed or displaced teeth, fractured teeth with pulp exposure, lacerations of the oral mucosa, acute dental pain, acute alveolar abscess, infection and uncontrolled bleeding [1-7].

Pain is the primary cause for the demand for emergency care [8-12] and approximately $90 \%$ of the dental emergencies are of pulp or periapical origin [13]. Dental emergencies comprise a wide spectrum of clinical presentations, which include irreversible pulpitis, acute alveolar abscess, lost restorations and dental bleeding [14].

Thus, the aim of this study was to evaluate the demographic profile of patients and clinical characteristics of dental emergencies at the outpatient clinic of the State University of Campinas - Piracicaba Dental School (FOPUNICAMP; Piracicaba, SP, Brazil) in order to determinate the prevalence and necessities of this population.

\section{METHODS}

The present study was approved by the FOPUNICAMP ethics research committee (protocol: 035/2013). Records from the first attendance of adult patients assisted for dental emergencies at the university outpatient clinic during a 12-months period were evaluated. Patients with deciduous teeth or poorly-filled records that did not allow proper evaluation of data were excluded. Patients records included:
- Anamnesis - Patient's gender, age, systemic condition and the main complaint responsible for the emergency visit;

- Clinical and radiographic exams - Clinical examination and periapical radiography of the affected tooth;

- Pulp and periapical tests - Percussion, palpation, and cold thermal test with carbon dioxide $\left(-50^{\circ} \mathrm{C}\right)$ (EndoFrost, Roeko, Langenau, Germany).

- Procedure(s) performed - Endodontic emergency; provisional restoration; temporary bonding; conservative pulp treatment; prosthesis adjustment; occlusal adjustment; or other procedures;

- Need of post-operative medication.

Patient's records and attendance was performed by the undergraduate students supervised by graduat e students and professors.

\section{Statistical analysis}

The resulting data were tabulated in an Excel spreadsheet (Microsoft, Seattle, WA, USA) and analysis was performed by using the SAS software (SAS Institute Inc. The SAS System, Release 9.3, Cary, NC, USA). The results were expressed as absolute or relative frequency and the chi-square test was used to verify the presence or absence of statistical significance at a level of $5 \%$.

\section{RESULTS}

In total, 1.345 patients records (average age $=39$ years old) were selected in the university outpatient 
clinic database. Female patients $(63.1 \% ; \mathrm{p}<0.001)$, with $29-48$ years $(42 \% ; p<0.001)$ was the most prevalent profile in the dental emergencies attendance. Dental pain was the most reported complaint during visits $(53.3 \% ; p<0.001)$, followed by tooth fracture $(19.9 \%)$ (Table 1).
Figure 1 shows pulp and periapical diagnosis, revealing that irreversible pulpitis was the most common diagnosis, with 299 cases (30.4\%; p<0.001). Moreover, it was also found that 309 teeth had already been endodontically treated. Most patients attended the service due to fracture of the temporary restoration $(192 / 62.1 \%)$

Table 1. Dental complaints reported during visits. (Page 4, first paragraph of the results).

\begin{tabular}{|c|c|c|c|}
\hline Dental complaints & Frequency & Percentage (\%) & P-value \\
\hline Fractured tooth & 266 & 19.9 & \\
\hline Fractured tooth and pain & 94 & 7 & \\
\hline Loss of provisional crown & 81 & 6 & $<0.001$ \\
\hline Swelling & 36 & 2.6 & \\
\hline Pain in third molars & 21 & 1.6 & \\
\hline Dental mobility & 17 & 1.3 & \\
\hline Sensitive tooth & 11 & 0.8 & \\
\hline Poorly adapted restoration & 4 & 0.3 & \\
\hline Total & 1345 & 100 & \\
\hline
\end{tabular}

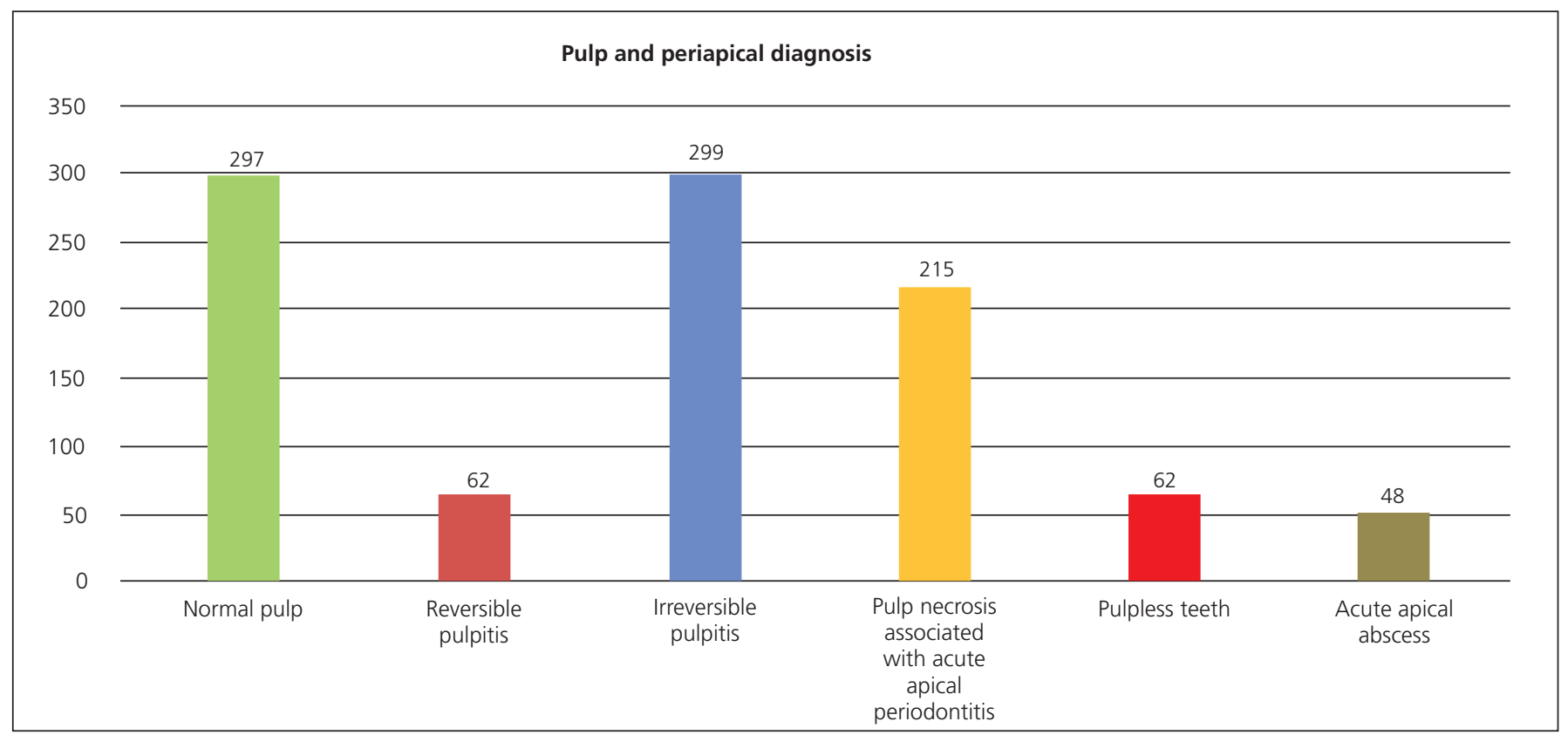

Figure 1. Pulp and periapical diagnosis (983 cases). 
followed by pain symptoms, which required endodontic retreatment (44/14.2\%), and therefore they were referred to endodontic specialists. Thirty-one $(10 \%)$ needed prothesis, 30 (9.7\%) were referred to dental surgery due to indication of extraction, $12(3.9 \%)$ needed occlusal adjustment.

In terms of clinical inspection, it was observed that decayed teeth $(323 / 25 \%, p<0.001)$ were the most frequently encountered condition, followed by teeth with permanent restoration (215/16.6\%), teeth with cavities (196/15.2\%), teeth with temporary restoration $(190 / 14.7 \%)$, fractured teeth $(156 / 12.1 \%)$, healthy teeth $(91 / 7 \%)$, prosthesis with posts $(77 / 6 \%)$ and prosthesis with no posts (44/3.4\%). Lower molars (401/29.8\%, p $<0.001$ ) were the most prevalent teeth, followed by upper molars (277/20.6\%), upper incisors (199/14.8\%), upper premolars $(174 / 12.9 \%)$, lower premolars $(126 / 9.4 \%)$, upper canines $(55 / 4.1 \%)$, lower incisors $(43 / 3.2 \%)$, lower canines (17/1.3\%) and edentulous patients (53/3.9\%).

It was found that systemic conditions were reported by the patients during the interview, such as hypertension (215/16\%), diabetes (33/2.5\%), heart disease $(13 / 1 \%)$, psychiatric disorders $(13 / 1 \%)$, hypertension and diabetes (12/0.9\%), hypothyroidism (12/0.9\%), pregnancy $(7 / 0.4 \%)$ and other conditions (31/2.3\%), with the majority of them showing no alteration $(1009 / 75 \%, p<0.001)$. With regard to the need of post-operative medication for patients, in most cases it was not necessary (1288/95.7\%). However, when needed, both antibiotics and analgesics were prescribed in 27 cases ( $2 \%)$, followed by analgesics in 14 cases $(1 \%)$, antibiotics in 4 cases $(0.4 \%)$, and antiinflammatory drugs, steroids or other medications in 12 cases $(0.9 \%)$.
Table 2 shows the procedures performed at the emergency department, with endodontic emergency being the most required service. Furthermore, 337 patients were referred to other areas of the dental school after anamnesis and clinical examination, since it was found that they did not require urgent care.

\section{DISCUSSION}

Pain is a complex phenomenon involving not only the sensory response, but also emotional, conceptual and motivational aspects of the behavior, one of the main reasons why people seek emergency services worldwide $[14,15]$. In this study, dental pain is the chief complaint reported by most patients, corresponding to 717 cases, which is also corroborated by Munerato et al. [16], Estrela et al. [17] and De-Paula et al. [18], although other studies have reported dental traumas and dental abscesses as the reasons for seeking emergency services $[19,20]$.

With regard to the pulp and periapic diagnosis, irreversible pulpitis is characterized by severe and spontaneous pain, being the most frequent pulp change. Pulp necrosis associated with acute apicalperiodont it is, which is charqacterized by severe pain during chewing and on percussion test, being the most prevalent periapical diagnosis. All these are in agreement with Munerato et al. [16], Menini et al. [21], Estrela et al. [17], Cachovan et al. [22] and Farmakis et al. [23]. The fact that pain of endodontic origin is the main reason why patients seek emergency services highlights the importance of having well-trained dentists to provide a prompt and effective care for pain [11]. In this study, the diagnosis of normal pulp corresponded to $32.3 \%$ of the cases, being more

Table 2. Procedures performed at the emergency department. (Page 5, last paragraph of the results)

\begin{tabular}{|c|c|c|c|}
\hline Procedure performed & Frequency & Percentage (\%) & P-value \\
\hline Provisional restoration & 240 & 23.8 & \\
\hline Temporary bonding & 105 & 10.4 & \\
\hline Conservative pulp treatment & 62 & 6.2 & $<0.001$ \\
\hline Occlusal adjustment & 32 & 3.2 & \\
\hline Other procedures & 74 & 7.3 & \\
\hline Total & 1008 & 100 & \\
\hline
\end{tabular}


associated with the need for restoration because the presence of restorative material fracture was frequently seen, and for this reason, the patients sought the service for new restoration. On the other hand, teeth diagnosed with reversible pulpitis had conservative treatment of the dental pulp.

With regard to periapical changes, it was noted that 48 teeth $(4.9 \%)$ were diagnosed with acute apical abscess - a low incidence for this type of alteration in the emergency service. Pulpless teeth, which were submitted to early endodontic treatment, accounted for 62 cases (6.3\%) of the 1,292 teeth evaluated - a low prevalence as well. This finding was also reported by Menini et al. [21], who found a failure rate of $7.4 \%$ in the endodontic emergency treatment of 500 teeth evaluated in a study conducted in the same emergency service. Cheng et al. [24] reported an incidence of $5 \%$ of visits after endodontic emergency treatment of a total of 3,696 cases studied. The need for another emergency care may be related to either failure in biomechanical preparation or incorrect filling of the root canal with intracanal medication. Endodontically treated teeth were observed in 309 cases, demonstrating that most patients with this condition seek the emergency service due to breakage of the provisional restoration. This also shows that non-definitive restorative treatment can lead to coronary infiltration or tooth loss, thus resulting in failure of endodontic treatment [25-27]. In addition to breakage of the provisional restoration, some patients seek the emergency service due to pain symptoms associated with the presence of periapical lesion, which demonstrates the failure of the original endodontic treatment.

Female patients (63.1\%) were found to be more likely to seek the emergency service in Brazil, which is corroborated by Abbud et al. [28], Munerato et al. [16], Menini et al. [21], Estrela et al. [17] and Sanchez and Drumond [29]. On the other hand, studies conducted in other countries, such as Bae et al. [19], Cachovan et al. [22] and Verma and Chambers [20], reported that emergency dental care is mostly sought by men. The higher rate of female patients can be explained by the importance they give to health care, including cultural and social factors, since women are usually responsible for taking children and the elderly to healthcare [29]. In addition, in most cases, men only seek dental care when pain is too strong to bear, often resulting in tooth extraction. The most frequent age group ranges from 29 to 48 years old, which is in agreement with previous studies, such as Menini et al. [21] and Sanchez and Drummond [29]. The prevalence of dental emergencies in this age group may be related to the fact that these individuals are more likely to have the largest number of teeth.

It was observed that most of the teeth assessed in patients attending the service had the presence of caries, which differs from study by De-Paula et al. [18], who reported that fractured teeth were the most prevalent condition. It was also noted that molars were the most affected teeth, which is corroborated by Menini et al. [21]. This could be explained by the fact that these teeth erupt earlier than other permanent dental elements. In addition, together with their anatomy and position in the arch, which makes oral hygiene more difficult, molars are more likely to suffer decay and consequently are at higher risk of developing pulp or periapical disease.

With regard to medical history, it was found that $25 \%$ of the patients reported some systemic condition, mainly hypertension. However, a study by Cachovan et al. [22] showed that systemic conditions were present in $41.4 \%$ of the cases, with cardiovascular diseases being the most prevalent conditions. Therefore, it is important to monitor blood pressure because hypertension is often asymptomatic, and the dentist should know the limits in which an urgent dental procedure can be performed, including selection of anesthetic agent and recommended maximum doses, and when to refer the patient to a physician. Moreover, emergency services must be properly prepared for the care of patients with any systemic condition.

The present study showed that most patients had no need for post-operative systemic medication, which corresponds to $95.7 \%$, suggesting a rational prescription of medications. The environment where the study was conducted, that is, an emergency service provided by a public dental school, might have contributed to this rational prescription, and our findings may not be similar to those of other emergency services. For most patients were prescribed antibiotics and analgesics, especially in cases of acute apical abscesses, and only analgesics in cases of irreversible pulpitis. The study by Kaptan et al. [30] reported antibiotics prescription rates of $21.7 \%$ and $41 \%$ in cases of acute apical periodontitis and acute apical abscesses, respectively, thus differing from our results. Another more recent study found that $83.9 \%$ of the patients attending an emergency department of a dental school in Brazil had no systemic drug prescribed after treatment [18]. With 
these results, it can be seen that in the majority of cases, both correct diagnosis and clinical intervention have been effective for treatment of endodontic emergency patients, since single-drug therapy is not enough for pain relief. Therefore, the use of antibiotics is an important treatment option only when clinically indicated, since this requirement can be associated with possible adverse effects, such as allergic reactions and development of microbial resistance.

With regard to the procedures performed, it was noted that the most prevalent one was that related to endodontic emergency, corresponding to 462 cases, with diagnosis of irreversible pulpitis, pulp necrosis associated with acute apical periodontitis, pulpless teeth and acute apical abscess. With these data, we can see the high frequency of visits of endodontic origin in the emergency services. These results are similar to those found elsewhere. Menini et al. [21] found 500 cases over a period of 15 months, De-Paula et al. [18] found $31.6 \%$ of visits of endodontic origin for over a period of two years, Cachovan et al. [22] reported $67.8 \%$ of endodontic emergencies in seven years, Abbud et al. [28] observed $27 \%$ in ten years, and Munerato et al. [16] reported $44.1 \%$ of visits of endodontic origin during the period of six months. However, Bae et al. [19] observed that suture was the most performed procedure, whereas Sanchez and Drummond [29] found that most visits were related to extraction. Referrals to other specialty areas of the dental school were observed in 337 visits, showing that despite the increased demand for endodontic emergency, many people seek this type of service because it is available. In other words, it is an opportunity to begin their treatment in order to solve oral health problems, even not conceptually meeting the emergency criteria. Thus, patients complaining of pain are more likely to meet the emergency criteria than those who do not express pain symptoms [29].

\section{CONCLUSION}

Considering the above-discussed issues in the present study, it is important to carry out research on the most relevant data of patients seeking dental emergency services, thus allowing measurements to be obtained for improvement of these services for the population.

It emphasize the need not only emergency service for the population who often do not have access to regular dental care, but also diagnosis and effective treatment for pain relief.
Acknowledgments

The authors thank Marcelo Corrêa Alves for statistical analysis support. This study was financed in part by the Coordenação de Aperfeiçoamento de pessoal de Nível Superior Brasil (CAPES) - Finance Code 001

\section{Collaborators}

AC Pereira, JFA Almeida, AA Zaia, BPFA Gomes, AJ Soares conceived and designed the study. AC Pereira and $A C C L$ Cerqueira Neto perform data collection. AC Pereira, JFA Almeida, AJ Soares analyzed and interpreted the data. AC Pereira, ACCL Cerqueira-Neto, AJ Soares wrote the manuscript.

\section{REFERENCES}

1. Davies GM, Duxbury JT, Boothman NJ, Davies RM, Blinkhorn AS. A staged intervention dental health promotion to reduce early childhood caries. Community Dent Health. 2005; 22(2):118-22.

2. Seppänen L, Lauhio $A$, Lindqvist $C$, Suuronen R, Rautemaa. Analysis of systemic and local odontogenic infection complications requiring hospital care. J Infect. 2008;57(2):116-22. http://dx.doi.org/10.1016/j.jinf.2008.06.002

3. Al-Dajani M, Limeback $\mathrm{H}$. Emerging science in the dietary control and prevention of dental caries. J Calif Dent Assoc. 2012;40(10):799-804.

4. Allareddy V, Rampa S, Lee MK, Allareddy V, Nalliah RP. Hospital-based emergency department visits involving dental conditions: profile and predictors of poor outcomes and resource utilization. J Am Dent Assoc. 2014;145(4):331-7. http://dx.doi.org/10.14219/jada.2014.7

5. Cohen LA, Magder LS, Manski RJ, Mullins CD. Hospital admissions associated with nontraumatic dental emergencies in a Medicaid population. Am J Emerg Med. 2003;21(7):540-4. https://doi.org/10.1016/j.ajem.2003.08.013

6. Okunseri C, Pajewski N, Brousseau D, Tomany-Korman S, Synder A, Flores G. Racial and ethnic disparities in nontraumatic dental condition visits to emergency departments and physician offices: a study of the Wisconsin Medicaid program. J Am Dent Assoc. 2008;139(12):1657-66. https://doi.org/10.14219/jada.archive.2008.0108

7. Adekoya N. Reasons for visits to emergency departments for Medicaid and State Children's Health Insurance Program patients: United States, 2004. N C Med J. 2010;71(2):123-30.

8. Mani SP, Cleaton-Jones PE, Lownie JF. Demographic profile of patients who present for emergency treatment at Wits' Dental School. J Dent Assoc S Afr. 1997;52(2):69-72.

9. Agostini FG, Flaitz CM, Hicks MJ. Dental emergencies in a university based pediatric dentistry postgraduate outpatient clinic: a retrospective study. ASDC J Dent Child. 2001;68(56):316-21. https://doi.org/10.14219/jada.archive.2008.0108 
10. Sakai VT, Magalhães AC, Pessan JP, Silva SMB, Machado MAAM. Urgency treatment profile of 0 to 15 year-old children assisted at urgency dental service from Bauru Dental School, University of São Paulo. J Appl Oral Sci. 2005; 13(4):340-4. http://dx.doi.org/10.1590/\$1678-77572005000400005

11. O'Keefe EM. Pain in endodontic therapy: preliminary study. J Endod. 1976; 2(10):315-9. http://dx.doi.org/10.1016/S00992399(76)80047-7

12. Campanelli CA, Walton RE, Williamson AE, Drake DR, Qian F. Vital signs of the emergency patient with pulpal necrosis and localized acute apical abscess. J Endod. 2008;34(3):264-7. http://dx.doi.org/10.1016/j.joen.2007.11.022

13. Hasselgren G, Calev D. Endodontics emergency treatment sound and simplified. N Y State Dent J. 1994;60(6):31-3.

14. Trivedy C, Kodate N, Ross A, Al-Rawi H, Jaiganesh T, Harris T, et al. The attitudes and awareness of emergency department (ED) physicians towards the management of common dentofacial emergencies. Dent. Traumatol. 2012; 28(2):121-6. http://dx.doi.org/10.1111/j.1600-9657.2011.01050.x

15. Lipton JA, Ship JA, Larach-Robinson D. Estimated prevalence and distribution of reported orofacial pain in the United States. J Am Dent Assoc. 1993; 124(10):115-21. https://doi. org/10.14219/jada.archive.1993.0200

16. Munerato $M C$, Flaminghi DL, Petry $P C$. Urgências em Odontologia: um estudo retrospectivo. Rev Fac Odontol. 2005;46(1):90-5.

17. Estrela C, Guedes OA, Silva JA, Leles CR, Estrela CRA, Pécora JD. Diagnostic and clinical factores associated with pulpal and periapical pain. Braz Dent J. 2011;22(4):306-11. http://dx.doi. org/10.1590/S0103-64402011000400008

18. De-Paula KB, Silveira LS, Fagundes GX, Ferreira MBC, Montagner F. Patient automedication and professional prescription pattern in an urgency service in Brazil. Braz Oral Res. 2014;28(1):1-6. http://dx.doi.org/10.1590/1807-3 107BOR-2014.vol28.0041

19. Bae, JH, Kim YK, Choi YH. Clinical characteristics of dental emergencies and prevalence of dental trauma at a university hospital emergency center in Korea. Dent Traumatol. 2011;27(5):374-8. http://dx.doi.org/10.1111/J.1600-9657.2011. 01013.x

20. Verma S, Chambers I. Dental emergencies presenting to a general hospital emergency department in Hobart, Australia. Aust Dent J. 2014;59(3):329-33. http://dx.doi.org/10.1111/adj. 12202

21. Menini MO, Gomes BPFA, Ferraz CCR, Souza Filho, JF, Zaia AA. Avaliação do sucesso clínico do atendimento de urgência endodôntica na FOP-Unicamp. Rev Assoc Paul Cir Dent. 2007;61(1):39-43.

22. Cachovan G, Phark JH, Schön G, Pohlenz P. Odontogenic infections: an 8-year epidemiologic analysis in a dental emergency outpatient care unit. Acta Odontol Scand. 2013;71(3-4):518-24. http://dx.doi.org/10.3109/00016357.2 012.696694

23. Farmakis ER, Palamidakis FD, Skondra FG, Nikoloudaki G, Pantazis N. Emergency care provided in a Greek dental school and analysis of the patients' demographic characteristics: a prospective study. Int Dent J. 2016;66(5):280-6. http://dx.doi. org/10.1111/idj.12245

24. Cheng Y, Cheung GS, Bian Z, Peng B. Incidence and factors associated with endodontic inter-appointment emergency in a dental teaching hospital in China. J Dent. 2006;34(7):516-21. https://doi.org/10.1016/j.jdent.2005.12.003

25. Ray HA, Trope M. Periapical status of endodontically treated teeth in relation to the technical quality of the root filling and the coronal restoration. Int Endod J. 1995;28(1):12-8. https:// doi.org/10.1111/j.1365-2591.1995.tb00150.x

26. Ricucci D, Gröndahl K, Bergenholtz G. Periapical status of root-filled teeth exposed to the oral environment by loss of restoration or caries. Oral Surg Oral Med Oral Pathol Oral Radiol Endod. 2000;90(3):354-9. https://doi.org/10.1067/moe. 2000.108802

27. Tronstad L, Asbjørnsen K, Døving L, Pedersen I, Eriksen HM. Influence of coronal restorations on the periapical health of endodontically treated teeth. Endod Dent Traumatol. 2000; 16(5):218-21.

28. Abbud R, Ferreira LA, Campos AG, Zanin KEG. Atendimento clínico de emergência: um estudo dos serviços oferecidos em dez anos. Rev Assoc Paul Cir Dent. 2002;56(4):271-5.

29. Sanchez HF, Drumond MM. Atendimento de urgências em uma Faculdade de Odontologia de Minas Gerais: perfil do paciente e resolutividade. RGO, Rev Gaúch Odontol. 2011;59(1):79-86.

30. Kaptan RF, Haznedaroglu F, Basturk FB, Kayahan MB. Treatment approaches and antibiotic use for emergency dental treatment in Turkey. Ther Clin Risk Manag. 2013;9:443-9. https://doi.org/10.2147/TCRM.S52009

Received on: 10/11/2017 Final version resubmitted on: 19/7/2018 Approved on: 4/10/2018 